\title{
ДОСЛІДЖЕННЯ АНТИОКСИДАНТНИХ ВЛАСТИВОСТЕЙ ЕКСТРАКТУ ЗІ ШПИНАТУ ГОРОДНЬОГО ЛИСТЯ НА МОДЕЛІ ТЕТРАХЛОРМЕТАНОВОГО УРАЖЕННЯ ПЕЧІНКИ
}

Вступ. За сучасними даними, в Україні 20-30 \% усіх захворювань печінки становлять ії токсичні ураження. Пошук потенційних гепатопротекторів проводять в останні роки серед великої кількості лікарських речовин різного походження та структури, проте найперспективнішими виявились антиоксиданти природного, переважно рослинного, походження через низьку вартість та високий рівень безпечності.

Мета дослідження - вивчити антиоксидантні властивості густого екстракту зі шпинату городнього листя в експериментах на щурах, уражених тетрахлорметаном.

Методи дослідження. Експерименти проведено на 60 білих щурах-самцях, яким моделювали гостре токсичне ураження печінки шляхом введення дворазово (через день) тетрахлорметану у вигляді 50 \% олійного розчину в дозі 1,0 мл/кг маси тіла тварин. Об'єктом досліджень був густий екстракт зі шпинату городнього листя в дозі 150 мг/кг маси тіла. Експерименти проведено на 4-ту, 7-му та 10-ту доби розвитку токсичного гепатиту. Активність окиснювальних процесів і стан антиоксидантної системи оцінювали за вмістом ТБК-активних продуктів, 2,4-динітрофренілгідразонів, церулоплазміну, активністю каталази.

Результати й обговорення. Ураження щурів токсичними дозами тетрахлорметану супроводжувалось активацією процесів ліпопероксидації та окиснювальної модифрікації протеїнів, що призвело до розвитку оксидативного стресу в організмі. За цих умов відмічали зменшення активності антиоксидантної системи, на що вказувало пригнічення активності каталази в організмі уражених тварин. Застосування з метою корекції виявлених порушень густого екстракту зі шпинату городнього листя викликало зниження активованих окиснювальних процесів та відновлення захисно-компенсаторних сил організму, про що свідчила нормалізація активності каталази та вмісту церулоплазміну. Цей екстракт за ефективністю дещо відрізнявся від відомого гепатопротектора силімарину (карсилу), але наприкінці досліджень його вплив на показники оксидативного стресу мало відрізнявся від впливу препарату порівняння.

Висновок. Густий екстракт зі шпинату городнього листя за умов токсичного ураження печінки проявляє гепатопротекторні властивості, які реалізуються через антиоксидантний ефект. Це зумовлює доцільність подальшого вивчення даного лікарського засобу.

КЛЮЧОВІ СЛОВА: густий екстракт зі шпинату городнього листя; тетрахлорметанове ураження печінки; оксидативний стрес; антиоксидантна система.

ВСТУП. На сьогодні в усьому світі відзначають постійне зростання захворювань печінки, викликане несприятливим екологічним станом, надмірним вживанням алкоголю, розповсюдженням гепатотропних вірусів, зниженням імунологічної реактивності організму. За сучасними даними, в Україні 20-30 \% усіх захворювань печінки становлять її токсичні ураження [1].

Результати численних досліджень свідчать про важливу роль активації процесів вільнорадикального окиснення в патогенезі багатьох захворювань печінки [2-4]. Проте фрормування (с А. Я. Никифорук, Л. С. Фіра, П. Г. Лихацький, 2018. оксидативного стресу може мати певні особливості щодо частоти його виникнення, участі в ньому різних складових активації реакцій пероксидного окиснення ліпідів, вільнорадикального окиснення протеїнів, зниження активності ензимів антиоксидантного захисту та вираження всіх зазначених компонентів [5-7].

Пошук потенційних гепатопротекторів проводять в останні роки серед великої кількості лікарських речовин різного походження та структури [7], проте найперспективнішими виявились антиоксиданти природного, переважно рослинного, походження [8]. 3 численних гепатопротек- 
торів, представлених в Україні, популярними $є$ препарати рослинного походження через низьку вартість та високий рівень безпечності.

Показано [9], що в основі гепатопротекторних есректів таких фрітопрепаратів, як силібор, силібінін, легалон, Лів 52 тощо, лежать їх антиоксидантна дія та стабілізація біомембран. Пошук нових лікарських рослин із високим вмістом біологічно активних речовин, які б проявляли антиоксидантні властивості, безперервно триває.

Нашу увагу привернув шпинат городній, який містить білки, жири, вітаміни А, B $, \mathrm{B}_{2}, \mathrm{~B}_{6}, \mathrm{C}, \mathrm{K}$, P, PP, D, E, H, мінеральні солі, органічні сполуки фреруму, калію, кальцію, фросфрору, магнію, натрію, багато йоду, сапоніни, фрлавоноїди, органічні кислоти (лимонну, серотинову, щавлеву), вуглеводи (глюкозу, фрруктозу, сахарозу) [9]. У складі протеїнів $€$ всі незамінні амінокислоти. Більшість із цих речовин має антиоксидантні властивості, які зможуть проявлятися при застосуванні лікарських засобів $з$ даної рослини за токсичних уражень печінки, що супроводжуються активацією окиснювальних процесів.

Мета дослідження - вивчити антиоксидантні властивості густого екстракту зі шпинату городнього листя в експериментах на щурах, уражених тетрахлорметаном.

МЕТОДИ ДОСЛІДЖЕННЯ. Експерименти проведено на 60 білих щурах-самцях, яких утримували на стандартному раціоні віварію Тернопільського державного медичного університету імені І. Я. Горбачевського.

Як модель токсичного ушкодження клітин печінки використовують гепатотропну отруту тетрахлорметан $\left(\mathrm{CCl}_{4}\right)$, ураження яким призводить до інтенсифрікації вільнорадикальних процесів та зниження активності захисних сил в організмі [10]. Для дослідження ефрективності застосування густого екстракту зі шпинату городнього листя (ГЕШГ) як антиоксидантного засобу ми обрали модель ураження печінки щурів саме тетрахлорметаном, який вводили дворазово (через день) у вигляді 50 \% олійного розчину в дозі 1,0 мл/кг маси тіла тварин. Об'єктом досліджень був густий екстракт зі шпинату городнього листя в дозі 150 мг/кг маси тіла, препаратом порівняння - еталонний гепатопротектор рослинного походження силімарин під торговою маркою "Карсил" виробництва фрірми "Sopharma" (Болгарія), який щури отримували у вигляді 1 \% крохмальної суспензії в дозі 100 мг/кг маси тіла.

Піддослідних тварин було поділено на 4 групи: 1-ша - інтактний контроль (6 тварин); 2-га щури, уражені тетрахлорметаном (18 тварин); 3-тя - уражені тетрахлорметаном щури після використання густого ектракту зі шпинату городнього листя (18 тварин); 4-та - уражені тетрахлорметаном щури після застосування силімарину (18 тварин).

Евтаназію щурів проводили під тіопенталовим наркозом на 4-ту, 7-му та 10-ту доби дослідження. При виконанні експериментів дотримувались усіх правил Європейської конвенції про захист хребетних тварин, що використовуються для дослідних та інших наукових цілей (Страсбург, 1986) [11].

Для досліджень використовували сироватку крові та печінку піддослідних щурів. Із серця тварин забирали кров, яку центрифуугували при частоті обертання $1100 \mathrm{~g}$ упродовж 30 хв. Отриману сироватку крові (надосадову рідину) використовували для проведення досліджень. Відібрану печінку (250 мг) застосовували для отримання гомогенату за допомогою гомогенізатора магнітного "Silent Crusher S" після попередньої пердузії з 2,5 мл фрізіологічного розчину. Активність окиснювальних процесів і стан антиоксидантної системи після введення коригувальних чинників оцінювали за вмістом ТБК-активних продуктів (ТБК-АП) [12], 2,4-динітрооренілгідразонів (2,4-ДНФГ) [13], церулоплазміну (ЦП) [14], активністю каталази (КТ) [15]. Для статистичної обробки даних використовували параметричні (за Стьюдентом) та непараметричні (за Вілкоксоном) методи дослідження. Вірогідними вважали зміни при $\mathrm{p} \leq 0,05$ [16].

РЕЗУЛЬТАТИ Й ОБГОВОРЕННЯ. РеаКЦії пероксидного окиснення біомолекул відіграють провідну роль у розвитку процесів хімічного ушкодження клітин за інтоксикації організму ксенобіотиками [17]. Так, при його ураженні $\mathrm{CCl}_{4}$ розвивається оксидативний стрес, за якого генерація активних фрорм оксигену переважає їх елімінацію ензимними та неензимними системами антиоксидантного захисту клітин [6]. Вважають, що основним біохімічним механізмом активації окиснювальних процесів під час ушкодження організму $\mathrm{CCl}_{4} €$ утворення вільнорадикальних продуктів та активних фрорм оксигену, які стимулюють реакції пероксидної модифрікації біомолекул - ліпідів, білків і нуклеїнових кислот.

Після введення в організм щурів $\mathrm{CCl}_{4}$ було відмічено прогресуюче підвищення в сироватці крові та печінці вмісту ТБК-АП протягом усього експерименту (табл. 1).

До кінця дослідження (14-та доба після останнього потрапляння токсичного чинника в організм) вміст у сироватці крові щурів ТБК-АП в 1,9 раза перевищував рівень інтактного контролю. У печінці наприкінці експерименту цей по- 
Таблиця 1 - Вміст ТБК-активних продуктів у сироватці крові та печінці щурів, уражених

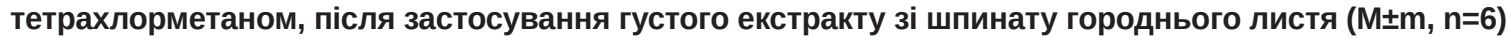

\begin{tabular}{|c|c|c|c|}
\hline \multirow{3}{*}{ Група тварин } & \multicolumn{3}{|c|}{ "Термін дослідження, доба } \\
\hline & 4-та & 7-ма & 10-та \\
\hline & \multicolumn{3}{|c|}{ Сироватка крові, мкмоль/л } \\
\hline Інтактний контроль & \multicolumn{3}{|c|}{$1,60 \pm 0,08$} \\
\hline Уражені $\mathrm{CCl}_{4}$ & $2,50 \pm 0,08^{*}$ & $2,89 \pm 0,14^{*}$ & $3,00 \pm 0,06^{*}$ \\
\hline 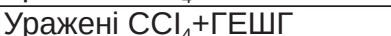 & $2,25 \pm 0,06$ & $2,08 \pm 0,07^{* *}$ & $1,92 \pm 0,08^{* *}$ \\
\hline Уражені $\mathrm{CCl}_{4}+$ +силімарин & $2,15 \pm 0,09 * *$ & $2,01 \pm 0,06^{\star \star}$ & $1,79 \pm 0,06^{\star \star}$ \\
\hline & \multicolumn{3}{|c|}{ Печінка, мкмоль/кг } \\
\hline Інтактний контроль & \multicolumn{3}{|c|}{$22,11 \pm 0,84$} \\
\hline Уражені $\mathrm{CCl}_{4}$ & $41,66 \pm 1,36^{*}$ & $48,82 \pm 1,03^{\star}$ & $50,10 \pm 1,54^{*}$ \\
\hline 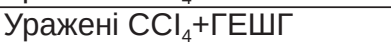 & $37,17 \pm 1,08$ & $28,09 \pm 1,40$ ** & $27,13 \pm 0,71^{\star \star}$ \\
\hline Уражені $\mathrm{CCl}_{4}+$ силімарин & $30,23 \pm 0,75^{\star \star}$ & $24,25 \pm 1,01^{\star \star}$ & $22,96 \pm 0,75^{\star \star}$ \\
\hline
\end{tabular}

Примітка. Тут і в таблицях 2, 3 та на рисунках 1, 2: * - вірогідні зміни між тваринами інтактного контролю та щурами, ураженими тетрахлорметаном; ** - вірогідні зміни між ураженими тваринами та щурами, яких піддавали корекції.

казник збільшився у 2,4 раза, що було підтвердженням гепатотропності даної отрути.

Застосування силімарину, відомого гепатопротектора та антиоксиданта, з метою пригнічення активованих процесів ліпопероксидації в ураженому організмі призвело до вірогідного зниження вмісту ТБК-АПу всі терміни дослідження як у сироватці крові, так і в печінці щурів.

Досліджуваний ГЕшГ проявив ефективний вплив на даний показник на 7-му та 10-ту доби експерименту, вірогідно знижуючи його (наприкінці дослідження вміст ТБК-АП у сироватці крові зменшився на $67 \%$ і практично досягнув рівня тварин інтактного контролю; в печінці вміст продуктів ліпопероксидації знизився на $104 \%$ щодо уражених щурів).

Отже, ураження тварин тетрахлорметаном викликає активацію окиснювальних процесів в організмі, зокрема ліпопероксидації, що проявляється збільшенням у досліджуваних тканинах проміжних ТБК-активних продуктів.

Активація процесів вільнорадикального окиснення призводить до дії активних фрорм оксигену і токсичних продуктів метаболізму на білкові компоненти мембран та інші білки організму, що викликає їх деградацію і зміни у структурі.

Таблиця 2 - Вміст 2,4-динітрофенілгідразонів (370) у сироватці крові та печінці щурів, уражених

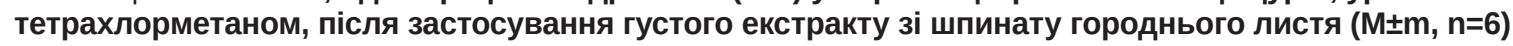

\begin{tabular}{|c|c|c|c|}
\hline \multirow{3}{*}{ Група тварин } & \multicolumn{3}{|c|}{ Термін дослідження, доба } \\
\hline & 4-та & 7-ма & 10-та \\
\hline & \multicolumn{3}{|c|}{ Сироватка крові, мкмоль/г протеїну } \\
\hline Інтактний контроль & \multicolumn{3}{|c|}{$0,44 \pm 0,03$} \\
\hline Уражені $\mathrm{CCl}_{4}$ & $0,82 \pm 0,02^{*}$ & $0,83 \pm 0,02^{*}$ & $0,86 \pm 0,02^{*}$ \\
\hline 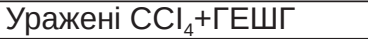 & $0,74 \pm 0,02$ & $0,70 \pm 0,02^{\star \star}$ & $0,67 \pm 0,02^{* *}$ \\
\hline Уражені $\mathrm{CCl}_{4}+$ силімарин & $0,73 \pm 0,02$ & $0,65 \pm 0,01^{* \star}$ & $0,58 \pm 0,01^{* *}$ \\
\hline Інтактний контроль & \multicolumn{3}{|c|}{$0,59 \pm 0,01$} \\
\hline Уражені $\mathrm{CCl}_{4}$ & $0,75 \pm 0,02^{\star}$ & $0,80 \pm 0,02^{*}$ & $0,85 \pm 0,07^{*}$ \\
\hline Уражені ССl + +ГЕШГ & $0,71 \pm 0,01$ & $0,75 \pm 0,03$ & $0,69 \pm 0,01^{\star \star}$ \\
\hline Уражені $\mathrm{CCl}_{4}+$ силімарин & $0,66 \pm 0,01^{\star \star}$ & $0,69 \pm 0,02^{\text {** }}$ & $0,62 \pm 0,01^{\star \star}$ \\
\hline
\end{tabular}

В експерименті після ураження щурів $\mathrm{CCl}_{4}$ спостерігали збільшення в їх сироватці крові та печінці вмісту продуктів окиснювальної модифікації протеїнів (2,4-динітрофенілгідразонів) як основного, так і нейтрального характеру.

3 таблиці 2 видно, що після потрапляння в організм щурів тетрахлорметану в сироватці крові вірогідно $(\mathrm{p} \leq 0,05)$ зростав вміст 2,4-ДНФГ (370) нейтрального характеру, який у всі терміни дослідження знаходився на одному рівні й тільки наприкінці експерименту був дещо більшим від попередніх показників (у цей час він перевищував рівень інтактного контролю у 2 рази).

У печінці щурів після ураження спостерігали прогресуюче зростання вмісту 2,4-ДНФГ нейтрального характеру, в останній термін дослідження він досягнув $144 \%$ щодо норми. Більш ефективним виявився силімарин, після застосування якого даний показник знижувався у всі терміни дослідження. Густий екстракт зі шпинату городнього листя призвів до вірогідного зменшення вмісту 2,4-ДНФГ в останні терміни дослідження.

Дослідження вмісту 2,4-ДНФГ (430) основного характеру показало аналогічне його збільшення в сироватці крові щурів 3 тетрахлорметановим ураженням печінки (рис. 1). 


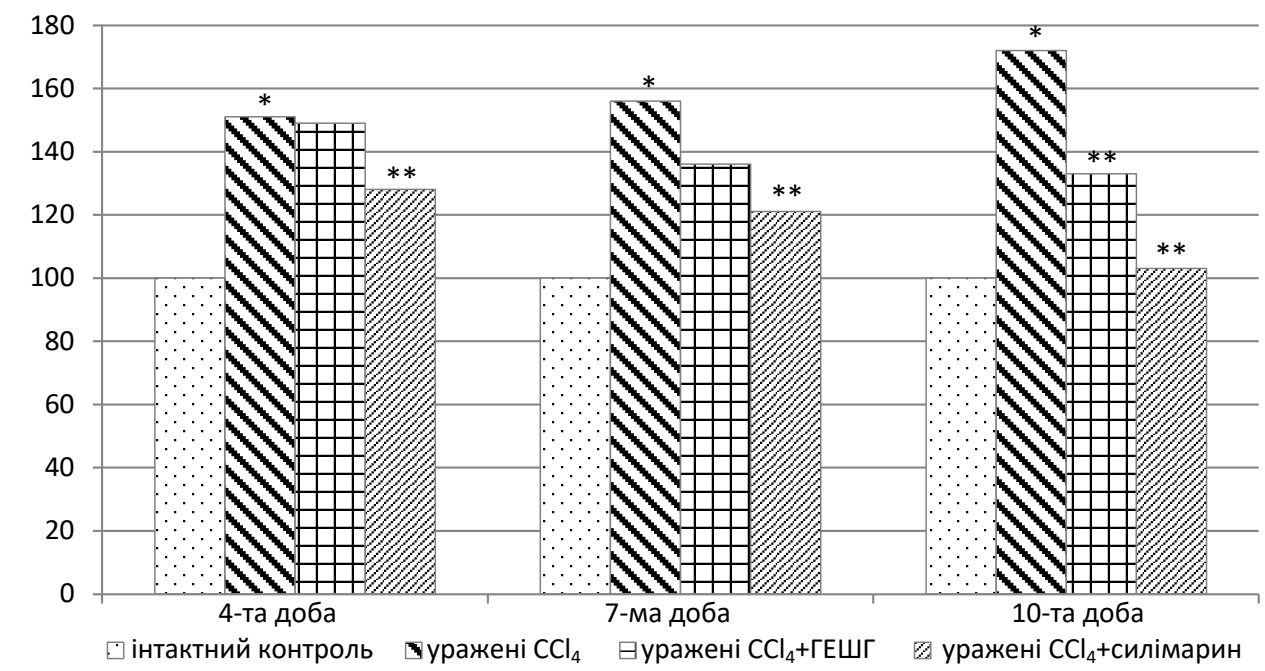

Рис. 1. Вміст 2,4-динітросренілгідразонів (430) основного характеру в сироватці крові щурів, уражених тетрахлорметаном, після застосування коригувальних чинників, \%.

Використані коригувальні чинники призвели до зниження вмісту продуктів ОМП (430) у сироватці крові, причому найбільше ефективність їх застосування проявилась наприкінці експерименту. Щодо досліджуваного екстракту, то він дещо поступався за ефрективністю силімарину.

У печінці щурів, уражених тетрахлорметаном, відзначали прогресуюче збільшення вмісту 2,4-ДНФГ (430), він досягнув максимуму на 10-ту добу дослідження. У цей термін ефективність застосування екстракту зі шпинату та силімарину була майже на одному рівні щодо даного показника.

Таким чином, після ураження печінки щурів тетрахлорметаном відбуваються процеси модисрікації протеїнових молекул, які призводять до нагромадження в сироватці крові та органах тварин альдегідо- і кетонопохідних цих сполук.

Застосовані коригувальні чинники проявили ефрективний вплив на процеси ліпопероксидації та окиснювальної модифрікації протеїнів, чим підтвердили свої антиоксидантні властивості.

Відомо, що про- й антиоксидантна системи перебувають у стані динамічної рівноваги, що підтримується певною організацією плазмових і клітинних ліпідів, мембранних фоосфроліпідів та холестеролу, які визначають ліпідний рівень окиснюваності клітинних мембран. Порушення прооксидантно-антиоксидантного гомеостазу $є$ потенційною передумовою розвитку оксидативного стресу [2, 4].

Антиоксидантна система захисту організму контролює та гальмує всі етапи вільнорадикальних реакцій - від їх ініціації до утворення гідропероксидів і малонового діальдегіду.
За умов тетрахлорметанового ураження печінки було доцільним дослідити деякі показники антиоксидантної системи та вплив на них густого екстракту зі шпинату городнього листя і порівняти його ефективність з ефективністю відомого гепатопротектора - силімарину.

Одним 3 основних антиоксидантів плазми крові $є$ церулоплазмін - купрумовмісний протеїн $\alpha_{2}$-глобулінової фрракції крові. Особливість цього протеїну полягає у високій стабільності до токсичної дії активних фрорм оксигену, що дозволяє йому зберігати біологічну активність за умов їх інтенсивної генерації [18].

Після ураження щурів тетрахлорметаном було досліджено вміст ЦП - білка з ензимною активністю, який бере участь у знешкодженні активних форм оксигену на початку зародження вільнорадикального ланцюга.

Протягом усього експерименту (10-ти діб) у сироватці крові тварин після отруєння тетрахлорметаном відмічали прогресуюче зростання вмісту ЦП (рис. 2).

Наприкінці експерименту вміст досліджуваного протеїну в сироватці крові перевищував рівень інтактного контролю на 55 \%. У початковий термін дослідження (4-та доба) до вірогідного зниження вмісту ЦП призвів тільки силімарин. Екстракт зі шпинату городнього листя та силімарин проявили однаковий вплив на цей показник у терміни 7 і 10 діб з моменту розвитку токсичного гепатиту.

Ми дослідили за умов тетрахлорметанового гепатиту активність каталази в сироватці крові та печінці щурів і відмітили ії зниження в обидвох досліджуваних тканинах (табл. 3).

Зниження активності КТ у сироватці крові та печінці щурів сприяє накопиченню токсичного продукту дисмутації супероксидного аніон-ради- 


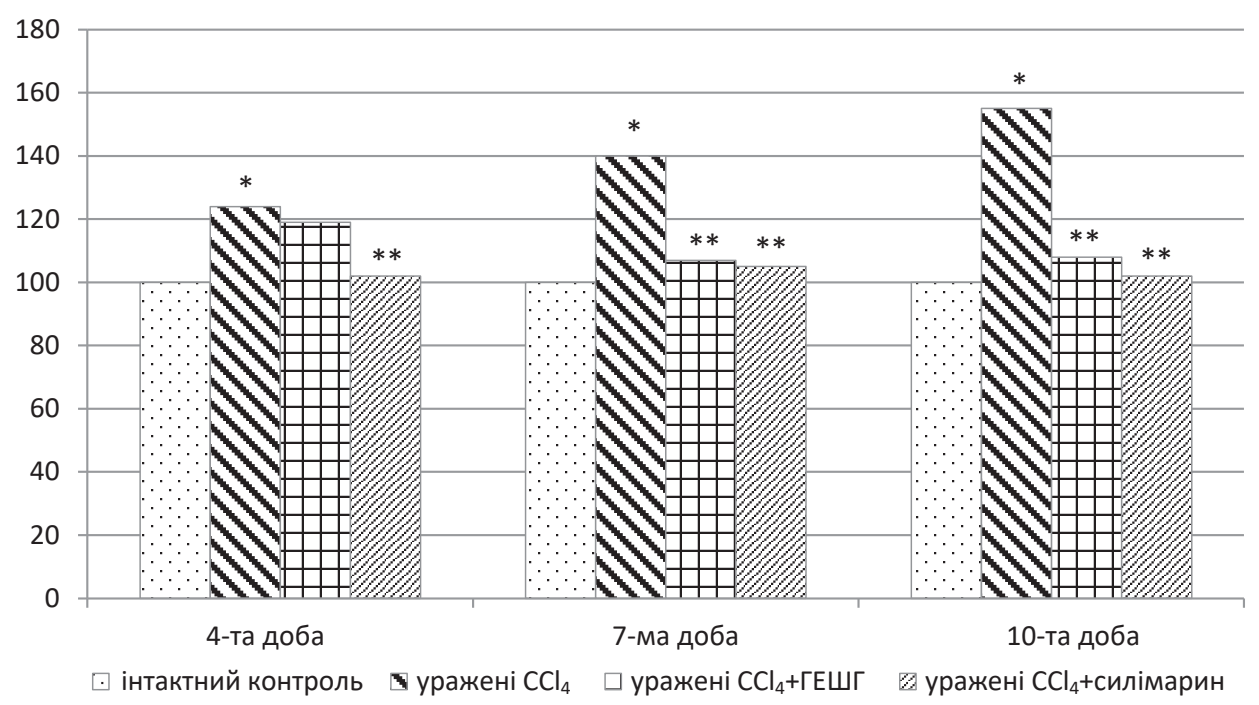

Рис. 2. Вміст церулоплазміну в сироватці крові щурів, уражених тетрахлорметаном, після застосування коригувальних чинників, \%.

Таблиця 3 - Активність каталази у сироватці крові та печінці щурів, уражених тетрахлорметаном, після застосування густого екстракту зі шпинату городнього листя $(\mathrm{M} \pm \mathrm{m}, \mathrm{n}=6)$

\begin{tabular}{|c|c|c|c|}
\hline \multirow{3}{*}{ Група тварин } & \multicolumn{3}{|c|}{ Термін дослідження, доба } \\
\hline & 4-та & 7-ма & 10-та \\
\hline & \multicolumn{3}{|c|}{ Сироватка крові, мкат/г протеїну } \\
\hline Інтактний контроль & \multicolumn{3}{|c|}{$0,230 \pm 0,007$} \\
\hline Уражені $\mathrm{CCl}_{4}$ & $0,150 \pm 0,006^{*}$ & $0,130 \pm 0,006^{*}$ & $0,140 \pm 0,007^{*}$ \\
\hline 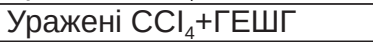 & $0,170 \pm 0,009$ & $0,210 \pm 0,006^{\star \star}$ & $0,220 \pm 0,005^{\star \star}$ \\
\hline Уражені $\mathrm{CCl}_{4}+$ силімарин & $0,210 \pm 0,007^{\star \star}$ & $0,220 \pm 0,008^{\star \star}$ & $0,230 \pm 0,004^{\star \star}$ \\
\hline & \multicolumn{3}{|c|}{ Печінка, мкат/г протеїну } \\
\hline Інтактний контроль & \multicolumn{3}{|c|}{$0,320 \pm 0,010$} \\
\hline Уражені $\mathrm{CCl}_{4}$ & $0,240 \pm 0,006^{*}$ & $0,210 \pm 0,009^{*}$ & $0,210 \pm 0,008^{*}$ \\
\hline Уражені ССІ + +ГЕШГ & $0,250 \pm 0,007$ & $0,230 \pm 0,009$ & $0,300 \pm 0,005^{\star \star}$ \\
\hline Уражені $\mathrm{CCl}_{4}+$ силімарин & $0,270 \pm 0,007^{\star \star}$ & $0,270 \pm 0,006^{\star \star}$ & $0,310 \pm 0,005^{\star \star}$ \\
\hline
\end{tabular}

кала - пероксиду гідрогену та свідчить про швидке виснаження системи антиоксидантного захисту за умов токсичних уражень організму, що призводить до ушкодження молекул ензимів продуктами пероксидного окиснення. Однією 3 причин зменшення активності КТ може бути викликана тривалою дією токсину деградація вільних та зв'язаних з мембранами ендоплазматичної сітки рибосом, які відповідають за синтез ензиму.

Силімарин проявив позитивний вплив на активність КТ як у сироватці крові, так і в печінці уражених тварин, вірогідно $(\mathrm{p} \leq 0,05)$ підвищуючи її в усі терміни дослідження. Густий екстракт зі шпинату городнього листя виявився ефективним щодо цього показника наприкінці експерименту. На 10-ту добу розвитку токсичного гепатиту в уражених щурів активність КТ у сироватці крові та печінці після застосування обох коригувальних чинників була практично на рівні інтактного контролю.
ВИСНОВКИ. Ураження щурів токсичними дозами тетрахлорметану супроводжується активацією процесів ліпопероксидації та окиснювальної модифікації протеїнів, що призводить до розвитку оксидативного стресу в організмі. За цих умов відмічають зменшення активності захисних сил організму, зокрема антиоксидантної, на що вказує пригнічення активності каталази в організмі уражених щурів. Застосування з метою корекції порушень, виявлених у системі прооксиданти/антиоксиданти, густого екстракту зі шпинату городнього листя викликає зниження активованих окиснювальних процесів та відновлення захисно-компенсаторних сил організму, на що вказує нормалізація активності каталази та вмісту церулоплазміну. Досліджуваний екстракт за ефрективністю дещо відрізнявся від відомого гепатопротектора з антиоксидантними властивостями - силімарину (карсилу), але наприкінці експерименту його вплив на показники оксидативного стресу мало відрізнявся від впливу препарату порівняння. 


\section{СПИСОК ЛІТЕРАТУРИ}

1. Гарбузенко Д. В. Механизмы компенсации структуры и фрункции печени при ее повреждении и их практическое значение / Д. В. Гарбузенко // Росс. журн. гастроэнтерологии, гепатологии, колопроктологии. - 2008. - 18, № 6. - С. 14-21.

2. Буеверов А. О. Оксидативный стресс и его роль в повреждении печени / А. О. Буеверов // Росс. журн. гастроэнтерологии, гепатологии, колопроктологии. 2006. - № 1. - C. 20-29.

3. Гріднєв О. Є. Перекисне окиснення ліпідів і печінка / О. Є. Гріднєв // Сучасна гастроентерологія. 2005. - 25, № 5. - С. 80-83.

4. Окислительный стресс. Патологические состояния и заболевания / [Е. Б. Меньщикова, Н. К. Зенков, В. З. Ланкин и др.]. - Новосибирск : Сибирское университетское издательство, 2008. - 284 с.

5. Бєленічев І. Ф. Антиоксидантна система захисту організму (огляд) / І. Ф. Бєленічев, Є. Л. Левицький, Ю. І. Губський // Сучасні проблеми токсикології. 2002. - № 3. - С. 24-29.

6. Гонский Я. И. Роль антиоксидантной системы в патогенезе токсического гепатита / Я. И. Гонский, М. М. Корда, И.Н.Клищ // Патологическая фризиология и экспериментальная медицина. - 1996. - № 2. C. 43-45.

7. Paul D. R. Reactive oxygen species (ROS) homeostasis and redox regulation in cellular signaling / D. R. Paul, Huang Bo-Wen, T. Yoshiaki // Cellular Signalling. - 2012. - 24, Issue 5. - P. $981-990$.

8. Громовая В. Ф. Антиоксидантные свойства лекарственных растений / В. Ф. Громовая, Г. С. Шаповал, И. Е. Миронюк // Химико-фрармац. журн. 2008. - 42, № 3. - С. 26-29.

9. Авдеева Е. В. Лекарственные растения, содержащие френилпропаноиды, как источник получения гепатопротекторных и иммуномодулирующих препаратов : авторефр. дисс. на соискание учен. степени д-ра фрармац. наук / Е. В. Авдеева ; Самарский ГМУ
Федерального агентства по здравоохранению и социальному развитию. - Пятигорск, 2007. - 49 с.

10. Экспериментальная модель токсического поражения печени и способы ее коррекции / М. А. Хильчук, Е. Е. Есауленко, А. А. Ладутько, И. М. Быков // Аллергология и иммунология. - 2012. - 13, № 1. C. 131.

11. Gross D. Ethics in animal-based research / D. Gross, R. Tolba // Eur. Surg. Res. - 2015. - 55, Issue 1-2. - P. 43-57. doi: 10.1159/000377721.

12. Лущак В. І. Показники оксидативного стресу. Тіобарбітурактивні продукти і карбонільні групи білків / В. І. Лущак, Т. В. Багнюкова, О. В. Лущак // Укр. біохім. журн. - 2004. - 76, № 6. - С. 136-141.

13. Дубініна О. Ю. Окиснювальний стрес і окиснювальна модифрікація білків / О. Ю. Дубініна // Мед. хімія. - 2001. - 3, № 2. - С. 5-12.

14. Ким Л. Б. Активность церулоплазмина у больных ишемической болезнью сердца / Л. Б. Ким, Т. Г. Филатова, Е. Ю. Калмыкова // Бюлл. СО РАМН. 2001. - № 4. - С. 30-35.

15. Королюк М. А. Метод определения активности каталазы / М. А. Королюк, Л. И. Иванова, И. Г. Майорова // Лаб. дело. - 1988. - № 1. - С. 16-19.

16. Okeh U. Statistical problems in medical research / U. Okeh // East. Afr. J. Public. Health. - 2009. - 6, Issue 1. - P. $1-7$.

17. Влияние интоксикации четыреххлористым углеродом на показатели белкового обмена в эксперименте / М. А. Хильчук, Е. Е. Есауленко, А. А. Ладутько, И. М. Быков // Гепатология сегодня : материалы XVII Конгресса (Москва, 19-21 марта 2012 г.). М., 2012. - С. 32.

18. Мжельская Т. И. Биологические функции церулоплазмина и их десрицит при мутации генов, регулирующих обмен меди и железа / Т. И. Мжельская // Бюлл. эксперим. биологии. - 2000. - 130, № 8. C. 124-133.

\section{REFERENCES}

1. Garbuzenko, D.V. (2008). Mekhanizmy kompensatsii struktury i funktsii pecheni pri yeye povrezhdenii i ikh prakticheskoye znacheniye [Mechanisms of compensation of the structure and function of the liver in case of its damage and their practical significance]. Rossiyskiy zhurnal gastroenterologii, gepatologii, koloproktologii Russian Journal of Gastroenterology, Hepatology, Coloproctology, 18 (6), 14-21 [in Russian].

2. Buyeverov, A.O. (2006). Oksidativnyy stress i yego rol v povrezhdenii pecheni [Oxidative stress and its role in liver damage]. Rossiyskiy zhurnal gastroenterologii, gepatologii, koloproktologii - Russian Journal of Gastroenterology, Hepatology, Coloproctology, 1, 20-29 [in Russian].

3. Hridniev, O.Ye. (2005). Perekysne okysnennia lipidiv i pechinka [Peroxidation of lipids and liver]. Suchasna hastroenterolohiia-Modern Gastroenterology, 25 (5), 80-83 [in Ukrainian].

4. Menshikova, Ye.N., Zenkov, N.K., Lankin, V.Z. Bondar, I.A., \& Trufakin, V.A. (2008). Okislitelnyy stress.
Patologicheskiye sostoyaniya i zabolevaniya [Oxidative stress. Pathological conditions and diseases]. Novosibirsk: Sibirskoye universitetskoye izdatelstvo [in Russian].

5. Byelenichev, I.F., Levytskyi, Ye.L., \& Hubskyi, Yu.I. (2002). Antyoksydantna systema zakhystu orhanizmu (ohliad) [Antioxidant system of organism protection (review)]. Suchasni problemy toksykolohii - Modern Problems of Toxicology, 3, 24-29 [in Ukrainian].

6. Gonskiy, Ya.I., Korda, M.M., \& Klishch, I.N. (1996). Rol antioksidantnoy sistemy v patogeneze toksicheskogo gepatita [The role of the antioxidant system in the pathogenesis of toxic hepatitis]. Patologicheskaya fiziologiya $i$ eksperimentalnaya meditsina - Pathological Physiology and Experimental Medicine, 2, 43-45 [in Ukrainian].

7. Paul, D.R., Bo-WenHuang, \& Yoshiaki, T. (2012). Reactive oxygen species (ROS) homeostasis and redox regulation in cellular signaling. Cellular Signalling, 24 (5), 981-990.

8. Gromovaya, V.F., Shapoval, G.S., \& Mironyuk, I.Ye. (2008). Antioksidantnyye svoystva lekarstvennykh raste- 
niy [Antioxidant properties of medicinal plants]. Khimikofarmatsevticheskiy zhurnal - Chemical-Pharmaceutical Journal, 42 (3), 26-29 [in Russian].

9. Avdeyeva, Ye.V. (2007). Lekarstvennyye rasteniya, soderzhashchiye fenilpropanoidy, kak istochnik polucheniya gepatoprotektornykh i immunomoduliruyushchikh preparatov [Medicinal plants containing phenylpropanoids as a source of hepatoprotective and immunomodulating drugs]. Doctor's Extended abstract. Pyatigorsk [in Russian].

10. Khilchuk, M.A., Yesaulenko, Ye.Ye., Ladutko, A.A., \& Bykov, I.M. (2012). Eksperimentalnaya model toksicheskogo porazheniya pecheni i sposoby yeye korrektsii [Experimental model of toxic damage to the liver and methods for its correction]. Allergologiya i immunologiya Allergology and Immunology, 13 (1), 131 [in Russian].

11. Gross, D., \& Tolba, R. (2015). Ethics in animalbased research. Eur. Surg. Res, 55, (1-2), 43-57.

12. Lushchak, V.I., Bahniukova, T.V., \& Lushchak, O.V. (2004). Pokaznyky oksydatyvnoho stresu. Tiobarbituraktyvni produkty i karbonilni hrupy bilkiv [Indicators of oxidative stress. These compounds are active products and carbonyl groups of proteins]. Ukr. biokhim. Zhurn. Ukrainian Biochemical Journal, 26, 136-141 [in Ukrainian].

13. Dubinina, Ye.Ye. (2001). Okysniuvalnyi stres i okysniuvalna modyfikatsiia bilkiv [Oxidative stress and protein oxidative modification]. Med. khimiya - Medical Chemistry, 2, 5-12 [in Ukrainian].
14. Kim, L.B., Filatova, T.G., \& Kalmykova Ye.Yu. Aktivnost tseruloplazmina u bolnykh ishemicheskoy boleznyu serdtsa [Ceruloplasmin activity in patients with ischemic heart disease]. Byul. SO RAMN. - Bulletin of the SO RAMS, 4, 30-35 [in Russian].

15. Korolyuk, M.A., Ivanova, L.I., \& Mayorova, I.G. (1988). Metod opredeleniya aktivnosti katalazy [Method of determining the activity of catalase]. Lab. delo. Laboratory Business, 1, 16-19 [in Russian].

16. Okeh, U. (2009). Statistical problems in medical research. East. Afr. J. Public. Health., 6 (1), 1-7.

17. Khilchuk, M.A., Yesaulenko, Ye.Ye., Ladutko, A.A., \& Bykov, I.M. (2012). Vliyaniye intoksikatsii chetyrekhkhloristym uglerodom na pokazateli belkovogo obmena $v$ eksperimente [The influence of carbon tetrachloride intoxication on the protein metabolism indicators in the experiment]. XVII Kongress "Gepatologiya segodnya", 19-21 marta 2012 g., Moscow: materialy kongressa - XVII Congress "Hepatology Today", March 19-21, 2012, Moscow: Congress Materials [in Russian].

18. Mzhelskaya, T.I. (2000). Biologicheskiye funktsii tseruloplazmina i ikh defitsit pri mutatsii genov, reguliruyushchikh obmen medi i zheleza [Biological functions of ceruloplasmin and their deficiency in the mutation of genes regulating the exchange of copper and iron]. Byulleten ekksperimentalnoy biologii - Bulletin of Experimental Biology, 130 (8), 124-133 [in Russian].

УЖГОРОДСКИЙ НАЦИОНАЛЬНЫЙ УНИВЕРСИТЕТ

ТЕРНОПОЛЬСКИЙ ГОСУДАРСТВЕННЫЙ МЕДИЦИНСКИЙ УНИВЕРСИТЕТ ИМЕНИ И. Я. ГОРБАЧЕВСКОГО

\section{ИССЛЕДОВАНИЕ АНТИОКСИДАНТНЫХ СВОЙСТВ ЭКСТРАКТА ИЗ ШПИНАТА ОГОРОДНОГО ЛИСТЬЕВ НА МОДЕЛИ ТЕТРАХЛОРМЕТАНОВОГО ПОРАЖЕНИЯ ПЕЧЕНИ}

\section{Резюме}

Вступление. По современным данным, в Украине 20-30 \% всех заболеваний печени составляют ее токсические поражения. Поиск потенциальных гепатопротекторов проводят в последние годы среди большого количества лекарственных веществ различного происхождения и структуры, однако наиболее перспективными оказались антиоксиданты природного, преимущественно растительного, происхождения из-за низкой стоимости и высокого уровня безопасности.

Цель исследования - изучить антиоксидантные свойства густого экстракта из шпината огородного листьев в экспериментах на крысах, пораженных тетрахлорметаном.

Методы исследования. Эксперименты проведены на 60 белых крысах-самцах, которым моделировали острое токсическое поражение печени путем введения двукратно (через день) тетрахлорметана в виде 50 \% масляного раствора в дозе 1,0 мл/кг массы тела животных. Объектом исследований был густой экстракт из шпината огородного листьев в дозе 150 мг/кг массы тела. Эксперименты проведены на 4-е, 7-е и 10-е сутки развития токсического гепатита. Активность окислительных процессов и состояние антиоксидантной системы оценивали по содержанию ТБК-активных продуктов, 2,4-динитрофренилгидразонов, церулоплазмина, активности каталазы.

Результаты и обсуждение. Поражение крыс токсическими дозами тетрахлорметана сопровождалось активацией процессов липопероксидации и окислительной модифрикации протеинов, что привело к развитию оксидативного стресса в организме. В этих условиях отмечали уменьшение активности антиоксидантной системы, на что указывало угнетение активности каталазы в организме пораженных 
животных. Применение с целью коррекции выявленных нарушений густого экстракта из шпината огородного листьев вызвало снижение активированных окислительных процессов и восстановление защитно-компенсаторных сил организма, о чем свидетельствовала нормализация активности каталазы и содержания церулоплазмина. Этот экстракт по эфррективности несколько отличался от известного гепатопротектора силимарина (карсила), но в конце исследований его влияние на показатели оксидативного стресса мало отличалось от влияния препарата сравнения.

Вывод. Густой экстракт из шпината огородного листьев в условиях токсического поражения печени проявляет гепатопротекторные свойства, которые реализуются через антиоксидантный эффрект. Это обусловливает целесообразность дальнейшего изучения данного лекарственного средства.

КЛЮЧЕВЫЕ СЛОВА: густой экстракт из шпината огородного листьев; тетрахлорметановое поражение печени; оксидативный стресс; антиоксидантная система.

A. Ya. Nykyforuk ${ }^{1}$, L. S. Fira ${ }^{2}$, P. H. Lykhatskyi² UZHHOROD NATIONAL UNIVERSITY ${ }^{1}$

I. HORBACHEVSKY TERNOPIL STATE MEDICAL UNIVERSITY²

\title{
STUDY OF ANTIOXIDANT PROPERTIES OF EXTRACT FROM LEAVES OF SPINATE ON A MODEL OF TETRACHLOROMETHANE LIVER DAMAGE
}

\begin{abstract}
Summary
Introduction. According to modern data, in Ukraine, 20-30\% of all liver diseases constitute its toxic lesions. The search for potential hepatoprotectors was carried out in recent years among a large number of medicinal substances of different origin and structure, however, natural antioxidants, mostly of plant origin, turned out to be the most promising because of their low cost and high level of safety.

The aim of the study - to investigate the antioxidant properties of a thick extract of garden spinach leaves in an experiment on rats affected by carbon tetrachloride.

Research Methods. The experiments were carried out on 60 white male rats, which simulated acute toxic liver damage by injecting carbon tetrachloride twice (every other day) in the form of a $50 \%$ oil solution at a dose of $1.0 \mathrm{ml} / \mathrm{kg}$ of animal body weight. The object of the study was a thick extract of spinach leaves at a dose of $150 \mathrm{mg} / \mathrm{kg}$ body weight. Studies were conducted on the $4^{\text {th }}, 7^{\text {th }}$ and $10^{\text {th }}$ day of the development of toxic hepatitis. The activity of oxidative processes and the state of the antioxidant system were assessed by the content of TBA active products and 2,4-dinitrophenylhydrazones, ceruloplasmin, catalase activity.

Results and Discussion. The defeat of rats with toxic doses of carbon tetrachloride was accompanied by the activation of lipid peroxidation and oxidative modification of proteins, which led to the development of oxidative stress in the body. Under these conditions, a decrease in the activity of the antioxidant system was observed, as indicated by the inhibition of catalase activity in the body of affected rats. Application for the purpose of correcting the identified violations of the dense extract from the leaves of garden spinach caused a decrease in the activated oxidative processes and the restoration of the protective-compensatory forces of the body, as indicated by the normalization of catalase activity and the content of ceruloplasmin. The studied extract was somewhat different in efficiency from the known silymarin hepatoprotector (Karsil), but at the end of the study its effect on oxidative stress indices differed little from the comparator drug.

Conclusion. The thick extract from the leaves of garden spinach under conditions of toxic liver damage exhibits hepatoprotective properties that are realized through the antioxidant effect. This leads to the expediency of further study of this medicinal product.
\end{abstract}

KEY WORDS: thick extract from garden spinach leaves; tetrachloromethane liver damage; oxidative stress; antioxidant system.

Отримано 07.11.18

Адреса для листування: Л. С. Фіра, Тернопільський державний медичний університет імені І. Я. Горбачевського, майдан Волі, 1, Тернопіль, 46001, Україна, e-mail: ludafira@ukr.net. 